\title{
Quantitative Analysis of Lysophosphatidic Acid in Human Plasma by Tandem Mass Spectrometry
}

\author{
Hohỵun Kim, Hỵe-Ràn Yoon, and Dongjin Pyo ${ }^{\dagger}$

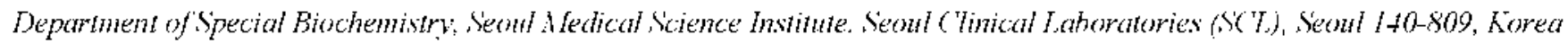 \\ Department of Chemistr: Kangi'on National hiversity, (huncheon 200-701, Korea \\ Receried Mav 13,2002
}

\begin{abstract}
Analysis of lysophosplatidic acids (LPAs) is of clinical importance as they can serve a potential marker for ovarian and other gynecological cancers and obesity: It is critically important to develop a highly sensitive and specific method for the early detection of grnecological cancers to improve the overall outcome of this disease. We have established a novel quantification method of LPAs in human plasma by negative ionization tandem mass spectrometry (MS-MS) using multiple reaction monitoring (MRM) mode without the conventional TLC step. Protein-bound lipids. LPAs in plasma were extracted with methanol : chloroforn (2:1) containing LPA $\mathrm{Cl} 4: 0$ as an internal standard under acidic condition. Following back extraction with chloroform and water. the centrifuged lower phase was evaporated and reconstituted in methanol. The reconstituted solution was directly injected into electrospray source of MS/MS. For MRM mode. Q1 ions selected were $\mathrm{m} / \mathrm{z} 409,433.435 .437$ and 4.57 which corresponds to molecular mass [M-H] of C16:0. C18:2, C18:1, C18:0 and C20:4 LPA. respectively. Q2 ions selected for MRM were $\mathrm{m} / \mathrm{z}$ 79. phosphoryl product. Using MS/MS with MRM mode. all the species of LPAs were completely separated from plasma matrix without severe interferences. This method allowed simultaneous detection and quantification of different species of LPAs in a plasma over a linear dynamic range of $0.01-25 \mu \mathrm{molL}{ }^{3}$. The detection limit of the method was $0.3 \mathrm{pmol} / \mathrm{mL}$. with a correlation coefficient of 0.9983 in most LPAs analyzed. When applied to the plasmas of normal and gy necological cancer patients. this new method differentiated two different groups by way of total LPA level.
\end{abstract}

Key words : Tandem mass spectrometry. Negative ionization. Multiple reaction monitoring. Ly sophosplatidic acid. Gy necological cancer

\section{Introduction}

In South Korea, ovarian cancer. which ranks first in incidence among grnecological cancers. caused an estimated 2.584 deaths in $20000^{1}$ More than $75 \%$ of women with ovarian cancer were diagnosed in an advanced stage. and the survival rate for these women remains very poor. If the disease were would be detected in stage $I$, the long-tern survival rate would be approximately $90 \%$. However. ovarian cancer develops silently: Symptoms usually occur only in advanced stages when tumor dissemination within the peritoneal cavity induces ascites. with the resultant increase in abdominal girth. Therefore it is critically important to develop a highly sensitive and specific method for the early detection of gynecological cancer to improve the overall outcome of this disease.

The search for a marker for ovarian cancer has been ongoing in many research laboratories over the last 20 years. More than 20 markers have been examined. including CA $125^{--}-\$$ Unfortunately; none of these markers effectively detect early stage ovarian cancer. although some of them are good prognostic markers and are very useful for ovarian cancer patient management. Transvaginal sonography can detect the early stage of the disease. but lacks specificity. In

\footnotetext{
"Author for corespondence: Phone: $+82-2-3461-0560$ ext 109 :

F.-mail: novakimsàyaboo.com
}

addition, such methods are too expensive to be widely used for screening. ${ }^{+}$The present study was conducted to determine whether lysophosphatidic acid (LPA) is important clinically as a potential marker for ovarian and other gynecological cancers and obesity.

Lysophosphatidic acid (1-acyl-2-hydroxy-sn-glycero-3phosphate. LPA). ${ }^{\text {lit }}$ once thought of only as an intermediate in the biosynthesis of phospholipids. has since been shown to be an important multifunctional biological mediator. LPA is the most widely studied example of a fanily of phospholipid growth factors whose members elicit their cellular effects through specific G-protein-coupled receptors. LPA elicits numerous cellular responses. including nitogentic ${ }^{11}$ and antimitogenic ${ }^{2}$ effects. on the cell cycle: regulation of the actin cy toskeleton. ${ }^{1.3}$ cellular motility. ${ }^{14}$ and cancer cell invasiveness. ${ }^{15}$ and mobilization of intracellular calciun. ${ }^{16.17}$ These pleiotropic growth factor-like effects have suggested roles for LPA as a factor in cellular homeostasis. ${ }^{18}$ a mediator of wound healing. ${ }^{19}$ and a modulator of carcinogenesis. ${ }^{2 i 1}$

Previous methods have utilized an indirect procedure to quantify the LPA level. Bioassays, such as voltage clamped Xenopus oocytes. ${ }^{11.22}$ have been used to generate titers of LPA-like activity: Although sensitive, this approach is callnot distinguish compound classes or molecular structures. Other investigators have analyzed LPA derived fatty acid methyl esters in an effort to determine LPA concentration. ${ }^{23}$ 
This methodology includes partial purification of LPA by thin-lay cr chromatography (TLC), followed by hydroly sis to generate fatly acid methyl esters for analysis by gas chromatography. Also. recent sludies used TLC for sample preparation and analyzed the resulted by clectrospray mass spectrometr. ${ }^{24}$ This protocol has two significant problems. First. appropriate standards for the control of recovery are lacking throughout the procedure. Second, various LPA salts (free acid. sodium and calcium salts) differ in mobility when chromatographed by TLC. This is true for acidic neuiral and basic TLC analysis. Both of these difficultics could lead to underestimation of LPA lcyels.

In the present study. we established a novel quantification method of LPAs in human plasma by turbo clectrospray ioni/ation tandem mass spectrometry (ESI-MS-MS). using multiple reaction monitoring (MRM) mode and precursor ion scan (PS) mode without the TLC sicp.

\section{Experimental Section}

Materials. LPAs (LPA Cl4:0. LPA C16:0. LPA C18:2. LPA C18:1. LPA C18:0 and LPA C20;4) were purchased from Avanti Polar Lipids Inc. (Alabaster. AL). Chlorolorm. acctic acid and hydrochloric acid werc purchased from Sigma-Aldrich Korca (Scoul. Korca). HPLC grade methanol and distilled water were purchased from Fisher Scientilic Korea (Seoul. Korea). Figure l presents the structures of the various LPA species analyzed.

ESI-MS-MS Conditions. MS-MS was performed on an APl 2000 triple quadrupole mass spectrometry cquipped with turbo electrospray ion source (PerkinElmer Life Science lnc. Boston. MA). Twenty microliters of sample were delivered into the ESI source. using a micro-LC cquipped with autosampler (PerkinElmer Scrics 200) withoul an LC column. The mobile phase used after degassing was $0.05 \%$ acctic acid in $95 \%$ methanol. Gradient clution of the mobile phase was from 200 to $400 \mu \mathrm{Lmin}^{-1}$ with a total tunning time of 1.5 min.

The instrument seltings were as follow: the turbo ionspray interface was maintaincd at $300{ }^{\circ} \mathrm{C}$ with a nitrogen nebulization. The nitrogen was kept at a pressure of $40 \mathrm{psi}$.

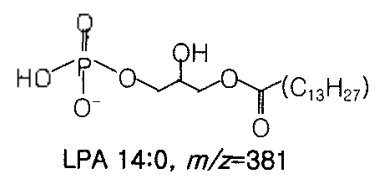

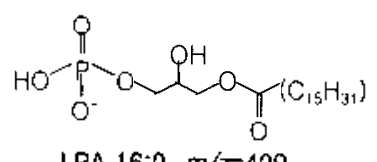

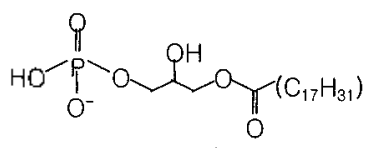

LPA $18: 2, m / 2=433$

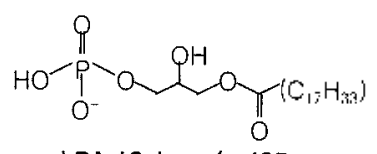

LPA 18:1, $m / z=435$

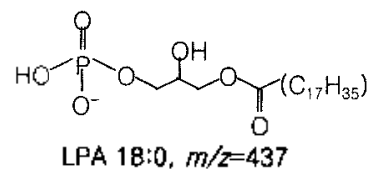<smiles>O=C(O)CCCCCC(OCC(O)COP(=O)([O-])O)C(=O)O</smiles>

Figure 1. Surciures of some lysophosphatidic acids (LPAs).
The turbo ion-spray drying gas ( $\left.\mathrm{N}_{-}\right)$was kept at a pressurc of $80 \mathrm{psi}$. For MRM scan mode with negative ion detection. the parameter setting was as follows -: The collision-activated dissociation gas (CAD) pressurc was 5 psi and curtain gas (CUR) pressure was 20 psi: lurbo ion-spray voltage. -4500 $\mathrm{V}$ : declustering potentials (DP). $-27 \mathrm{~V}$ to $-56 \mathrm{~V}$ : focusing potential (FP), $-390 \mathrm{~V}$ : cntrance potentials (EP), I0 V to I I $\mathrm{V}$ : collision cell cntrance potcntials (CEP). -55 to $-57 \mathrm{~V}$ : collision cnergies (CE). - $61 \vee$ to $-67 \mathrm{~V}$ : collision cell cxit potentials (CXP), $-11 \mathrm{~V}$ to $-12 \mathrm{~V}$ : deflector (DF). $-150 \mathrm{~V}$ and channel clectron multiplicr (CEM). $2300 \mathrm{~V}$. The parameter setting for the for the PS scan mode with negative ion detection was as follows: DP. $-56 \mathrm{~V}:$ FP. $-390 \mathrm{~V}:$ EP. $10 \mathrm{~V}$ : CEP. $-57 \mathrm{~V}$ : CE. $-67 \mathrm{~V}$ : and CXP. $-12 \mathrm{~V}$.

Sample Preparation. The blood samples of three patients and five healthy controls were centriluged at $3.000 \mathrm{rpm}$ for $15 \mathrm{~min}$ at $+{ }^{\circ} \mathrm{C}$. The plasma was transferred into coated microcentrifuge tubes (Supclco/Sigma. St. Louis. MO) and frozen at $-50^{\circ} \mathrm{C}$ or used immediately. All cxtraction procedures were performed in $1.5 \mathrm{~mL}$ microcentrifuge lubes. To $200 \mu \mathrm{L}$ of plasma sample. $40 \mu \mathrm{L}$ of $6 \mathrm{~N}$ hydrochloric acid and 800$) \mu \mathrm{L}$ of methanol : chloroform $(2 ; 1)$ containing LPA $\mathrm{Cl} 4: 0$ as internal standard were added. The plasma was voriexed for $1 \mathrm{~min}$ and incubated for $20 \mathrm{~min}$ at $-10{ }^{\circ} \mathrm{C}$. The upper phase was transferred to another tube to which were added $200 \mu \mathrm{L}$ of chloroform and $250 \mu \mathrm{L}$ of distilled water for liquid-liquid extraction. The lower phase taken was vorlexed for $1 \mathrm{~min}$ and incubated for $5 \mathrm{~min}$ at $-10^{\circ} \mathrm{C}$. After centrilugation $\left(13.000 \mathrm{rpm}\right.$ for $10 \mathrm{~min}$ at $4^{\circ} \mathrm{C}$ ). the lower phase was transferred to a new microcentrifuge tube and incubated for $30 \mathrm{~min}$ at $-50{ }^{\circ} \mathrm{C}$ for the removal of lipid residuc. The lower phase (100 $\mu \mathrm{L})$ was transferred to a 96 well-microplate (Costar. Cambridgc. MA). cvaporated under a gentle nitrogen stream at $40^{\circ} \mathrm{C}$ and redissolved in $100 \mu \mathrm{L}$ of methanol. The solution was directly injected into the turbo clectrospray ion sourcc of the ESI-MS-MS.

\section{Results and Discussion}

Xuet al. used two-dimensional TLC to separate LPA from other lipids. ${ }^{\text {?.5 }}$ All major lysophospholipids (LPLs) species. including lỵsophosphatidy lchloline (LPC). ly sophosphatidylcthanolaminc (LPE). lysophosphatidylglyccrol (LPG). lysophosphatidylinositol (LPI). lysophosphatidylscrine (LPS). lyso-platelet activating factor (LPAF) and PAF were separated in plasma with the solvent system (chlorofom : methanol : anmonium hydroxide $=65: 35: 5.5$ ). Although this TLC step showed the advantage of decreased siscosity of the extracts during the plasma preparation. it did not appear that the partial TLC purification sicp properly improsed sensitivity and specificity for the quantification of LPA due to the background fluctuation in the spectrum of product scan mode. ${ }^{-4}$ Therefore. we developed a novel quantification method for LPAs by negatixe ion ESI-MS-MS. especially using turbo ion clectrospray without tedious. time consuming and labor-intensive TLC clcan-up.

The linear dynamic range of LPA C16:0 and C18:0 


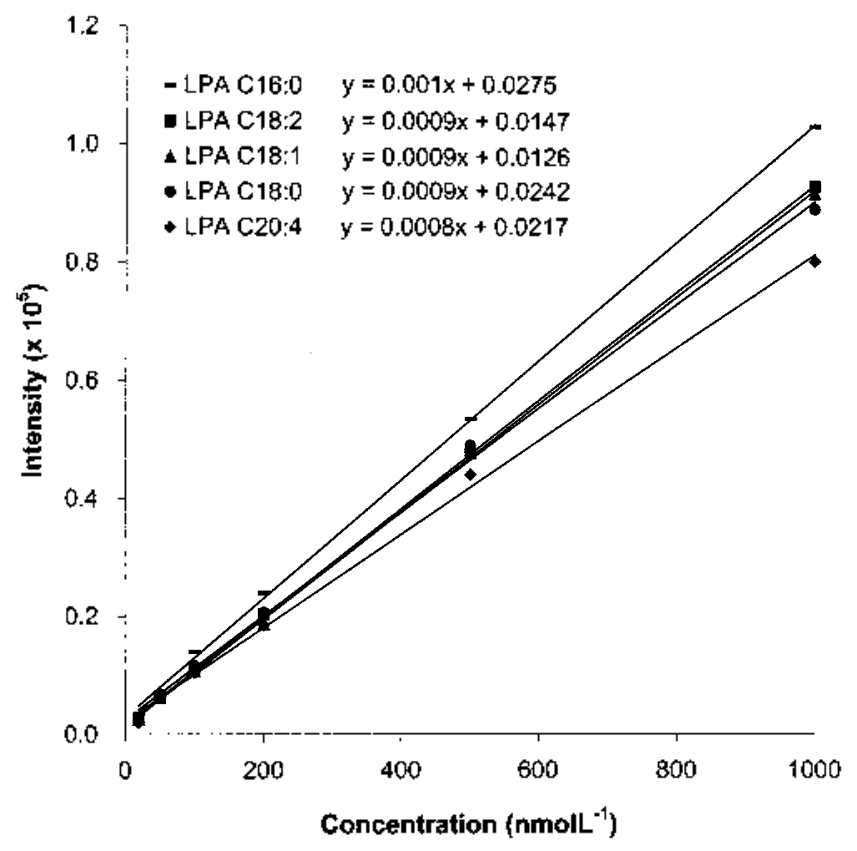

Figure 2. Calibration curve of $I, P A$ species.

Table 1. I.ineatity and detection limit of I,PA species

\begin{tabular}{|c|c|c|c|c|}
\hline \multirow{2}{*}{ LPAS } & \multicolumn{2}{|c|}{ Regression line" } & \multirow{2}{*}{$\begin{array}{l}\text { Correlation } \\
\text { cosliliciunt (I) }\end{array}$} & \multirow{2}{*}{$\begin{array}{l}\text { Detection limit } \\
\left.\text { (mmol } L^{-1}\right)\end{array}$} \\
\hline & $m$ & $b$ & & \\
\hline I.PACI $6: 0$ & 0.0010 & 0.0275 & 0.9983 & 1.0 \\
\hline I.PAC' $8: 2$ & 0.0009 & 0.0147 & 0.9987 & 0.5 \\
\hline I.PA C'I8:I & 0.0009 & 0.0126 & 0.9984 & 0.3 \\
\hline I.PA C $18: 0$ & 0.0009 & 0.0242 & 0.9986 & 0.5 \\
\hline I.PA C 20$) 4$ & 0.0008 & 0.0217 & 0.9991 & 0.5 \\
\hline
\end{tabular}

" $-m+b$

species were between $0.01 \mu \mathrm{molL}^{-1}$ and $25 \mu \mathrm{molL}^{-1}$. which is adequate for the detection of biologically excreted low concentration of LPA in plasma. The concentration of LPAs was calculated by measuring the height of cach LPA relative to that of interial standards following a calibration curve of each LPA (Figure 2). The regression lines for all LPAs show excellent linearity with a correlation cocfficient of higher than $0.9983 \mathrm{in}$ the range of $0.01-25 \mu \mathrm{molL}^{-1}$ (Table 1). The
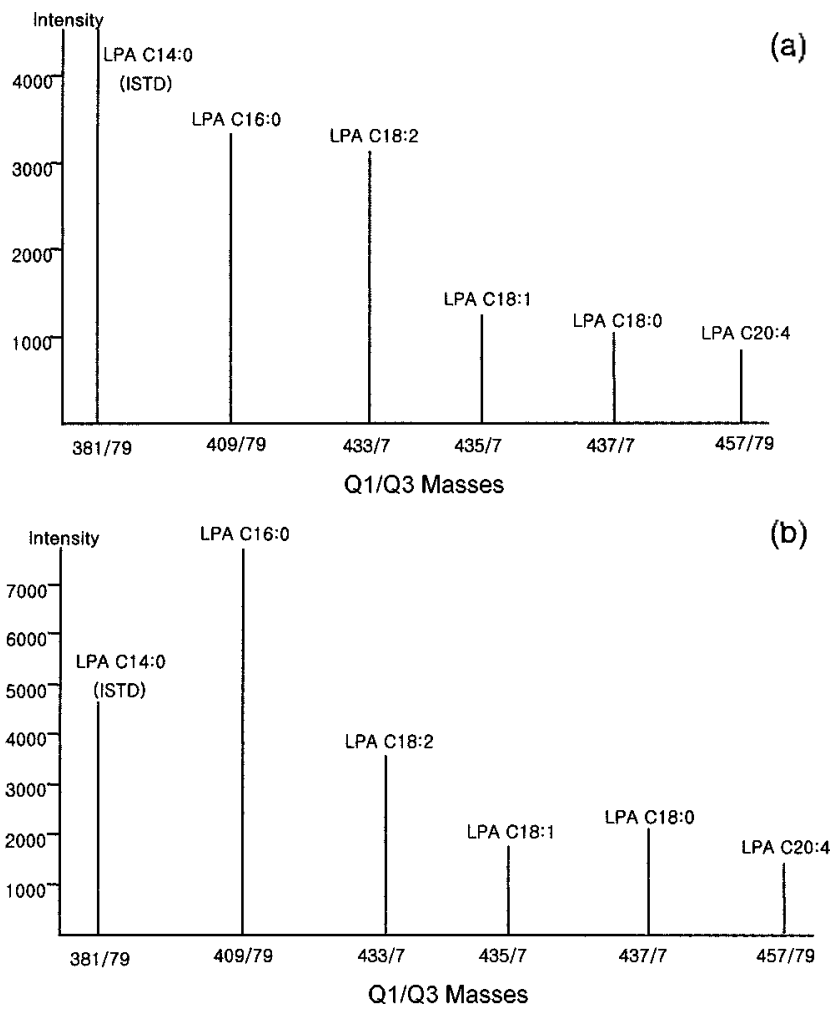

Figure 3. The MRM spectrum of I.PAs from plasma. (a) healthy control, (b) gynecological cancer patient.

detcetion limit for this method was $0.3-1.0 \mathrm{pmolmL}^{-1}$ for the quantification of LPAs in plasma.

Recowery ol LPA C 16:0 and C 18:0 was between 100 and $110 \%$. with RSD of less than $7 \%$ from the plasma fortificd with three different concentrations (0.1. 0.5 and I molmL $L^{-1}$ ) of LPAs (Table 2). This cxcellent recovery result proved the supcriority of our method in terms of reproducibility compared with that of $\mathrm{Xu}$ ef al. s method $^{30}$ which showed $70 \%$ of recovery with TLC procedure.

For achicying high sensitivity and specificity. we used both MRM and PS scan mode for the purpose of quantification and identification of LPAs. respectively: MRM spectrum (Figure 3) and PS spectrum (Figure 4) were presented from the plasmas of healthy control and gynccological

Table 2. Recovety, precision and accuracy data for quantification of I,PA C $16: 0$ and I.PA C 1800

\begin{tabular}{|c|c|c|c|c|c|c|c|c|c|}
\hline \multirow{2}{*}{$\begin{array}{l}\text { Conc. added } \\
\left(\text { ummols, }{ }^{-1}\right)\end{array}$} & & \multicolumn{4}{|c|}{ lnlcr-day assay ${ }^{a}$} & \multicolumn{4}{|c|}{ Intra-day assay? } \\
\hline & & $\begin{array}{l}\text { LPA } \\
\text { C.16:0 }\end{array}$ & $\begin{array}{c}\text { Recovery } \\
(\%)\end{array}$ & $\begin{array}{c}\text { LPA } \\
\text { C } 18: 0\end{array}$ & $\begin{array}{c}\text { Recovery } \\
(\%)\end{array}$ & $\begin{array}{l}\text { LPA } \\
\text { C16:0 }\end{array}$ & $\begin{array}{c}\text { Rocowry } \\
(\%)\end{array}$ & $\begin{array}{l}\text { LPA } \\
\text { C180 }\end{array}$ & $\begin{array}{c}\text { Recover } \\
(\%)\end{array}$ \\
\hline \multirow[t]{3}{*}{0.10} & Mênl & 0.10 & 100 & 0.11 & 110 & 0.10 & 100 & 0.11 & 110 \\
\hline & $\mathrm{SD}$ & 0.01 & & 0.01 & & 0.61 & & 0.01 & \\
\hline & $\% \mathrm{RSD}$ & 6.8 & & 4.7 & & 5.9 & & 5.7 & \\
\hline \multirow[t]{3}{*}{0.50} & Mcan & 0.50 & 100 & 0.52 & 104 & 0.50 & 100 & 0.52 & 104 \\
\hline & $\mathrm{SD}$ & 0.01 & & 0.01 & & 0.61 & & 0.61 & \\
\hline & $\% \mathrm{RSD}$ & 2.4 & & 2.5 & & 2.4 & & 2.5 & \\
\hline \multirow[t]{3}{*}{1.00} & Mcan & 1.01 & 101 & 1.03 & 103 & 1.61 & $10]$ & 1.63 & 103 \\
\hline & $\mathrm{SD}$ & 0.03 & & 0.02 & & 0.03 & & 0.02 & \\
\hline & $\% \mathrm{RSD}$ & 2.6 & & 2.3 & & 2.5 & & 1.8 & \\
\hline
\end{tabular}

"1n-5; number of independent replicate. 

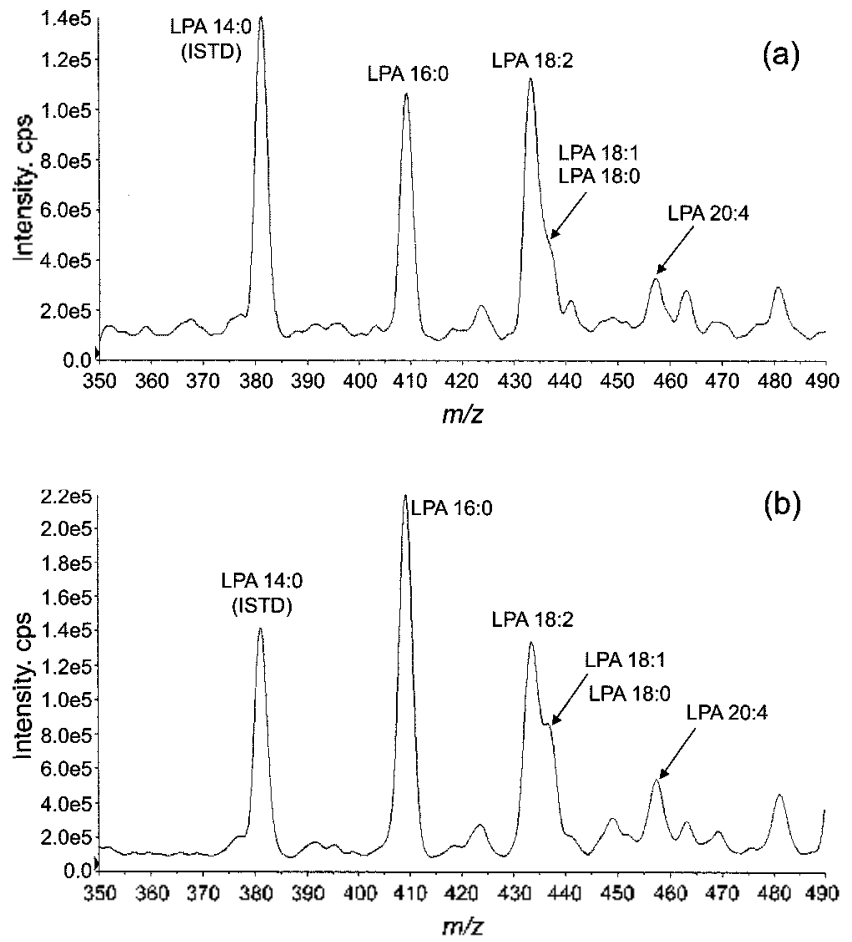

Figure 4. The PS spectrum of I.PAs from plasma. (a) healthy control, (b) grnecological cancer patient.

cancer patients. Figure 3 and 4 show an cxcellent mass spectrum. which minimired any interferences that could be derived from plasma.

We applied the new method to the plasmas from with normal and gynccological cancer paticnts. Total LPAs from plasma from grnecological cancer patients were 1.5 times higher than that from plasma from normal control (Table 3). showing that gynccological cancer patients are clcarly differentialed from normal control. This result implics the future possibility of the availability of LPAs as a biological marker for the early medical intervention for a varicty of gy necological cancer patients. To support the clinical use of this marker. a more intensive study should be performed with an extended large-scalc population.

In Table 3. we used total LPAs level for differentiating the patient from the normal. Howerer. if the levels of the palmiloyl LPA (Cl6:0). olcyl LPA (C18;1), and stcaroy] LPA (C18:1) are used as a biological marker. the difference

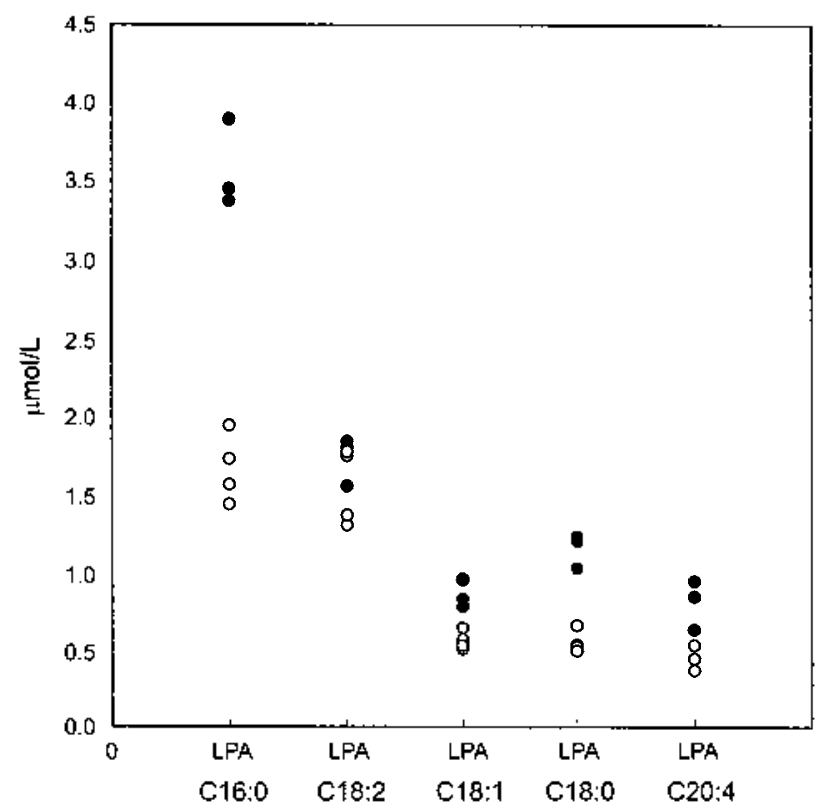

Figure 5. Concentration of LPAs in plasmas from healthy control $($ : $)$ and gynecological cancer patient $(\bullet)$.

between a healthy individual and a patient would be quite prominent as shown in Figure 5. It secms that this result may support and have some connection with the report by Xuet $a^{\prime \prime}{ }^{\text {T }}$ The ovarian cancer activating factor (OCAF) is composed of various species of LPA. including LPAs. with polyunsaturated fatty acyl chains. Howercr. OCAF is more potent than $s n-1$ of palmitoyl. olcyl. and stcroy $1 \mathrm{LPA}$ in increased $[\mathrm{Ca}]_{j}$ in ovarian cancer cells. ${ }^{25}$ Therefore this interesting linding will $b c$ an important consideration when we develop a strategy for further sudics.

The importance of this study is a new method dexclopment and its tentative craluation for clinical use for the diagnosis of gynccological cancers compared with a control in obstetric patients. Plasma LPA may represent a more sensitive maker for gynecological cancers. The plasma LPA assay offers the possibility of the diagnosis of gynecological cancers. a discase that is associated with a poor outcome mainly because it is rarely detected at carly stages.

We need to address the fact our results are preliminary and are based on a limited population. Further sudics will be able to verify the general usefulness of LPA as a biomarker

lable 3. Coneentration of I.PAs in plasmas from patients and healthy controls unit : pmoll. '

\begin{tabular}{lcccccc}
\hline Sample & I.PA C16:0 & I.PAC18:2 & I.PA C18:1 & I.PAC18:0 & I.PAC20:4 & Total \\
\hline Patient 1 $^{a}$ & 3.897 & 1.826 & 0.943 & 1.223 & 0.827 & 8.716 \\
Patient 2 $^{b}$ & 3.442 & 1.536 & 0.774 & 1.199 & 0.621 & 7.573 \\
Patient 3 $^{c}$ & 3.370 & 1.790 & 0.818 & 1.018 & 0.932 & 7.927 \\
\hline Control 1 $_{\text {Control 2 }}^{\text {Control 3 }}$ & 1.716 & 1.740 & 0.637 & 0.522 & 0.431 & 5.046 \\
Control 4 & 1.925 & 1.292 & 0.496 & 0.648 & 0.362 & 4.722 \\
\hline
\end{tabular}

"Female, 53Y, Primary peritoncal caremoma. "Female, 42Y, Kenckenterg tumor in both oraries "Female, 47Y, cervical carcinema. 
for gynecological cancers and whether a combination of LPA and other assays. such as CAl25, are even more useful for cancer detection.

\section{References}

1. Korea Nationel Statistical Oflice Ammal Report on the Ganse of Death Statistics: 2000.

2. Jacobs I.: I3ast Ir. R. C. Hum Repnd 1989 4. 1-12.

3. Oolas. R. P.: Xu. F. J.: Jacobs. I. J.: Yu. Y. H.: Daly. L.: Berchuck. A.: Soper. J. T.: Clarke-Pearson. D. L.: Oram. D. H.: Bast Jr. R. C. J. Natl Comcer Lnst. 1993. 85. 1748-1751.

4. Taylor, K. I.: Schuarta. P. I. Rudiolog 1994, 192. 1-1th

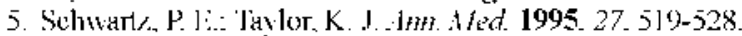

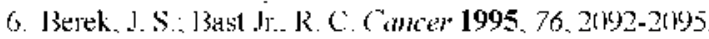

7. Mackcy. S. E.: Creasman. W. T. J. Clin. Oncol. 1995. 13. 783-793.

8. Chen. L. M.: Karlan. E. Y. (Wh. Obstet. Gintecol 1998. 41. 200214.

9. Xu. Y.: Shen, /.: Wiper 1). W: Wu, M.: Morton. R. Ii.: Ii]son. P. Kemedy, $\Lambda$. W.: Belinsous. I.: Markman. M.: Casey. (i. J.11L1 1998. $280.719-723$.

10. Van Corren. E. J.: Van Rijswijk. A.: Jalink. K: Van der Bend. R. L.: Van Blittersuijk. W. J.: Moolenaar. W. H. Biochem. J. 1992. 281. 163-169.

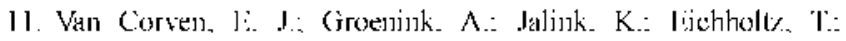
Moolenaar. W. I . Cell 1989, 59, 45-54

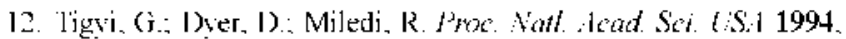
91. 1908-1912.
1.3. Ridley. A. J.: Hall. A. (. kl 1992. 70, 389-399

14. Thou. 1): Luini, W. Bemasconi, S. Diomede I..: Salmona. M.: Mantovani. A. Sozzani. S. f. Biol. (7heth. 1995, 270, 2554925556 .

15. Imamura. F.: Horai. T.: Mukai. M.: Shinkai. K.: Sawada. M.: Akedo. H. Biochen. Bioplows Res Conmm. 1993. 193. 497-503.

16. An. S: Bleu. T.: theng, Y.: (joetrl. I. J. Mol. Phormacol. 1998 54. $881-888$

17. lischer. 1). J: I,iliom, K: (juo, \%.: Nusser N.: Virag. 'T: Murakami-Murofushi. K.: Kobayashi. S.: Ericksont. T. R.: Sun. G.: Miller. D. D.: Tigvi. G. Mol. Phomacol 1998. 54.979-988.

18. Goetzl. E. J.: Lee. H.: Tigvi. G. J. Citotime Refences: Oppenheim. J. J : Lieldman. M.. Lids: Academic Press: San Diego, $20(k)$ pp $14107-1+18$

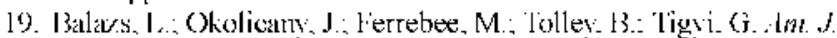
Phusiol. Regul Integrat Comp. Ihwsiol 2001. 280. R466-R472.

20. Xil. Y.: Fang. X. J.: Casev. G.: Mills. G. B. Bickhem. J 1945. 309. $933-940$.

21. Tigvi. ('.: Miledi. R. J. Biol. (7hem. 1992.267.21360)-21.367.

22. Tigvi. G.: Ilong. I.: Yakubu, M.: Parlenova. II: Shibala, M.:

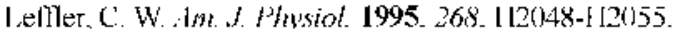

23. Tokumura. A.: Harada. K.: Fukuzawa. K.: Tsukatani. H. Biochim. Biophus. fcta 1986. 875.31-38

24. Xiao. Y.: Chen. Y.: Kennedy. A. W.: Belinson. J.: Xu. Y. thm. NY Acad Sci. 20M0. 905. 242-259.

25. Xu. Y.: (Taudette I) C . Bovnton. J. I): Frankel. A.: Fang. X. I.: Sharma A. Ilurteau, I.: Cásey G.: Goodbody, $A$.: Mellors. $\Lambda$. Holub. B. I.: Mills. G. B. Clin. Can. Res. 1995. I. 1223-1232. 